\title{
IDENTIFICATION OF GROUND INSTABILITY IN THE HOUSING ESTATE COMPLEX BASED ON GEORADAR AND SATELLITE RADAR INTERFEROMETRY
}

\author{
František HUBATKA ${ }^{1)}$, Lubomil POSPÍŠIL ${ }^{2)}$ and Milan LAZECKÝ ${ }^{3) *}$ \\ 1) KOLEJCONSULT \& servis, s r.o., Křenová 131/35, Trnitá, 60200 Brno, Czech Republic \\ 2) Department of Geodesy and Mining Engineering, Faculty of Mining and Geology, VSB - Technical University of \\ Ostrava, 17. listopadu 15/2172, 70833 Ostrava-Poruba, Czech Republic \\ 3) IT4Innovations, VSB - Technical University of Ostrava, 17. listopadu 15/2172, 70833 Ostrava-Poruba, Czech Republic
}

*Corresponding author's e-mail: milan.lazecky@vsb.cz

\section{ARTICLE INFO}

Article history

Received 11 January 2021

Accepted 6 April 2021

Available online 16 April 2021

Keywords:

Ground Penetrating Radar (GPR)

Measurement offset

Satellite Radar Interferometry

Geophysics

Subsidence

\begin{abstract}
Procedures of using ground penetrating radar (GPR) and Sentinel-1 satellite synthetic aperture radar (SAR) were tested in the area of housing estates in Hodonín, where there is an intensive decrease in the subsoil and thus a significant cracking of prefabricated houses. Extensive geophysical research of the site provided essential information about active faults in the area. To prove them and define the most active deformation zones (blocks), where the maximum settlement of the subsoil occurs, the processed interferometric (InSAR) data from the Sentinel-1 SAR satellite were used. Results from joint evaluation of geophysical data and InSAR not only confirmed detected deformations but also notified on other locations with tendencies to subsidence in the neighborhood of main faults. The combination of the methods to identify displacement tendencies in urbanized areas is very effective.
\end{abstract}

\section{INTRODUCTION}

Housing estate Bažantnice is a housing estate complex built in the 1950s and 1960s on the northwestern outskirts of the town of Hodonín. These are mostly three-storey residential houses of various standardized floor plans and sizes. They have a lowered basement at the level of -1.5 to $1.8 \mathrm{~m}$ below ground level. There is a total of 112 residential houses. There are also infrastructure facilities and school facilities.

From the geological point of view, the Bažantnice housing estate stands on an unstable subsoil, which has been working for decades. Houses crackle and tilt (Fig. 1). In addition, they are full of cracks, previously repaired by various means of reinforcing the partitions three years ago, but they continue to crack. People from seventeen houses in the Bažantnice housing estate in Hodonín are worried about their situation and prefer moving out immediately. But many do not have this option. About 17 apartment buildings lie on one of the faults in the Vienna Basin. They will need remediation.

House defects in the Bažantnice housing estate in Hodonín have been occurring for a very long time. It was once thought that the cause of the failures was the geological subsoil. A layer of clays adheres to the layers of sand, which shrink excessively during drying. The sands were saturated with water that rose into the clay. Some intervention in the subsoil significantly reduced the groundwater level, which resulted in the drying of clay and caused their shrinkage. Clays have different thicknesses and their susceptibility to shrinkage also varies, so there is an uneven settlement. Uneven settling caused house disturbances. So far, this has only been addressed by smearing cracks with concrete and supports.

The geological survey from 2007 contained only a few boreholes and only to a depth of six meters. However, it is assumed that a stable subsoil can be up to twelve meters below the surface. Other exploratory works, including geophysical ones, have revealed a network of faults and fracture systems, which, together with the dry season, may be the cause of these cracks in houses. The level of the local Morava River, which has dropped by up to a meter and a half in the last five years in the summer, also shows the lack of rainfall, and even dropped a month earlier than last year. And it is the water that the clay subsoil on which the houses are built needs. Fine-grained soils tend to shrink when they lose water. Maybe that's why cracks also appear on houses with which there have been no problems so far. Extensive geophysical and engineering geological works were carried out to solve the given situation (Fig. 2), which made it possible to clarify the basic tectonic structure in the given locality. A comprehensive geological-geophysical survey was supplemented by the results of interferometry on the basis of which the verification of movement 


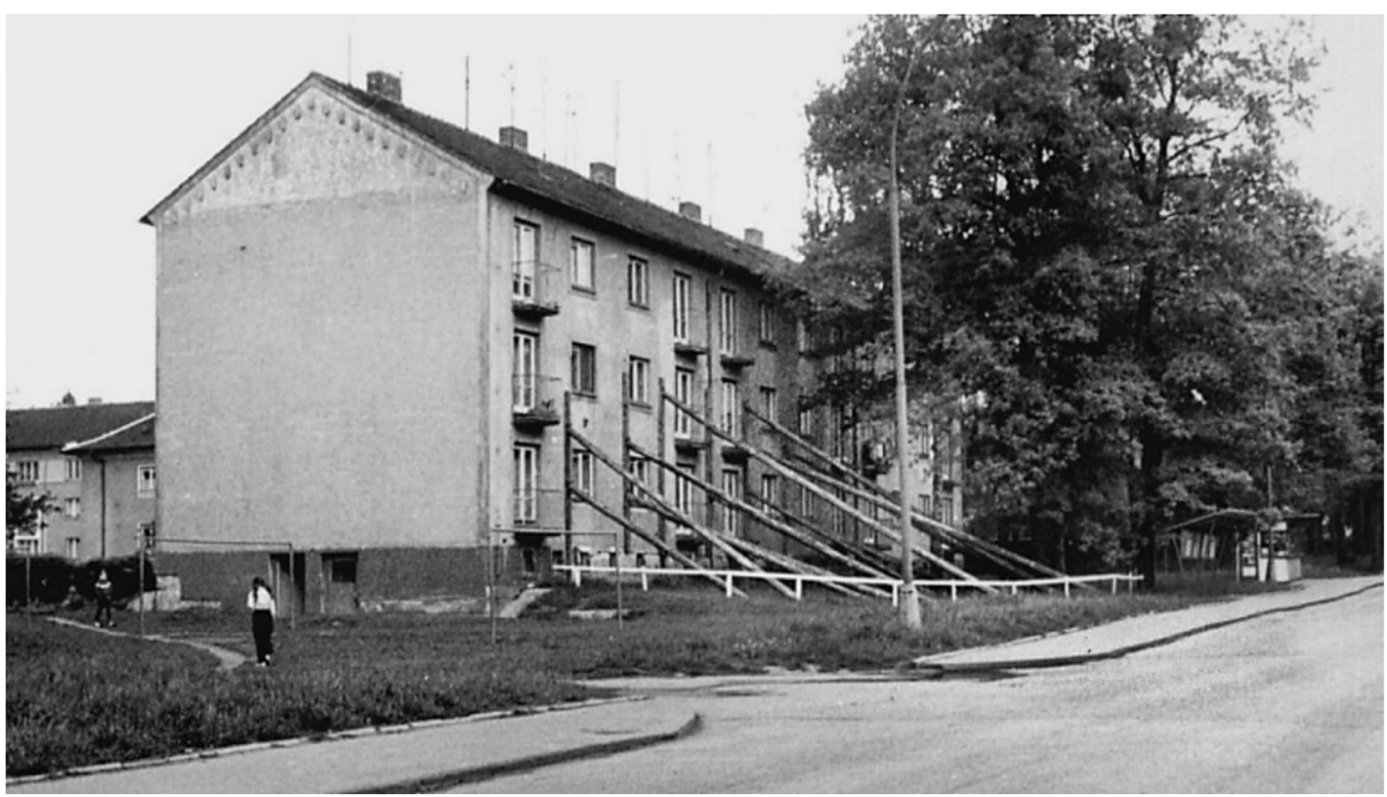

Fig. 1 An example of one of the housing estate blocks from the 1970s, when individual houses began to crack and tilt. Source: Municipality Office Břeclav.

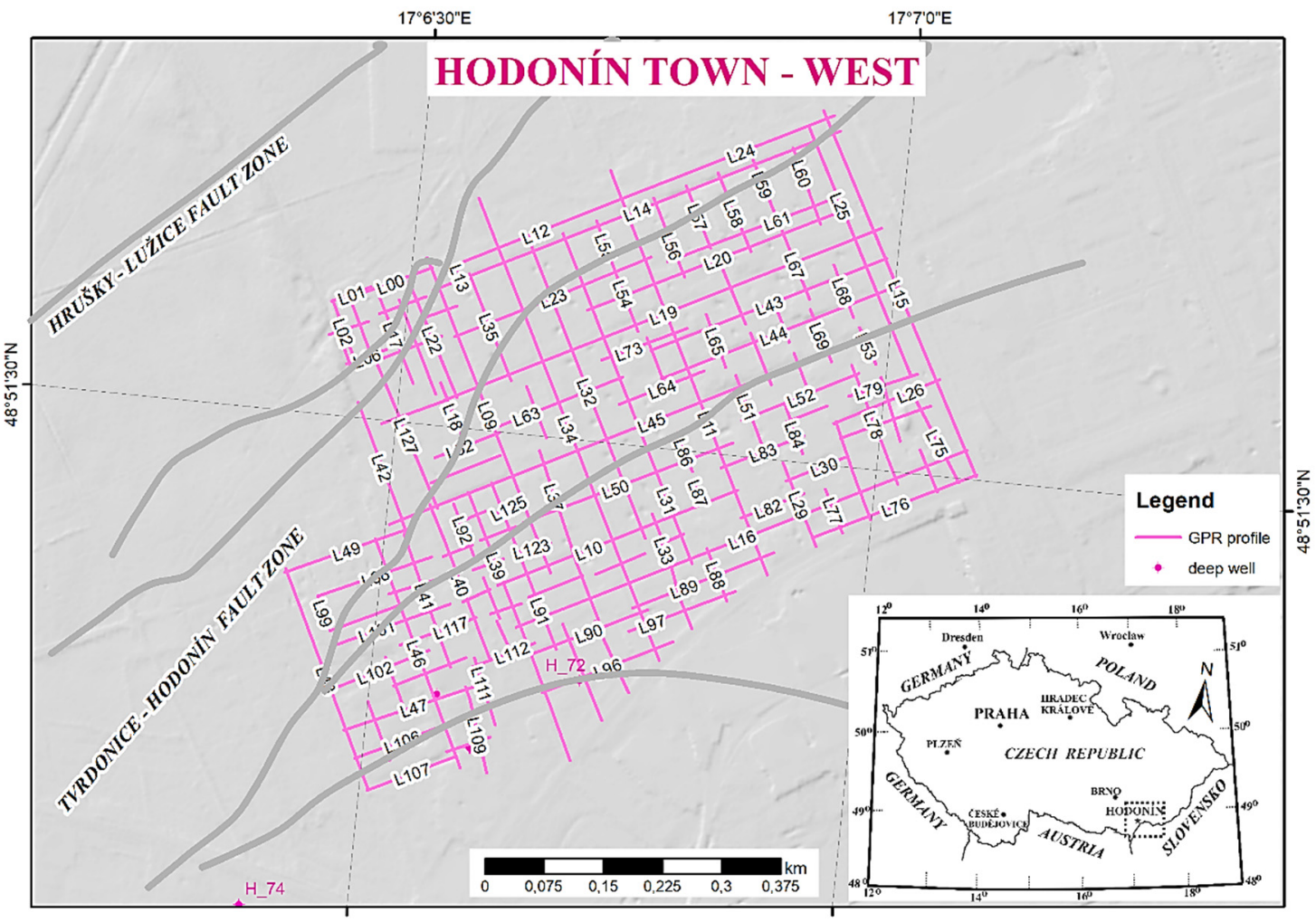

Fig. 2 Situation of exploratory geophysical works and location of main faults.

tendencies was performed. Based on these results, the location of places with higher subsidence was specified, the places of maximum deformations were defined, which also contributed to finding and clarifying the causes that cause the condition.

\section{BRIEF GEOLOGICAL CHARACTERISTICS}

The investigated locality in the town of Hodonín is located in the oldest hydrocarbon exploration area. Towards the SW is the first exploied oil deposit - Nesyt, which was only recently closed and recultivated. Other oil reservoirs in surrounding were transferred to Underground gas storage (UGS) facilities (e.g. Hrušky, Dol. Bojanovice), which the movement tendencies were recently investigated by Rapant et al. (2020). Their structural-tectonic position is connected by significant Tertiary faults - HruškyLužice and Tvrdonice - Hodonín. These faults point directly to the investigated locality (Fig. 2). Tvrdonice - Hodonín fault system in this area is divided into 


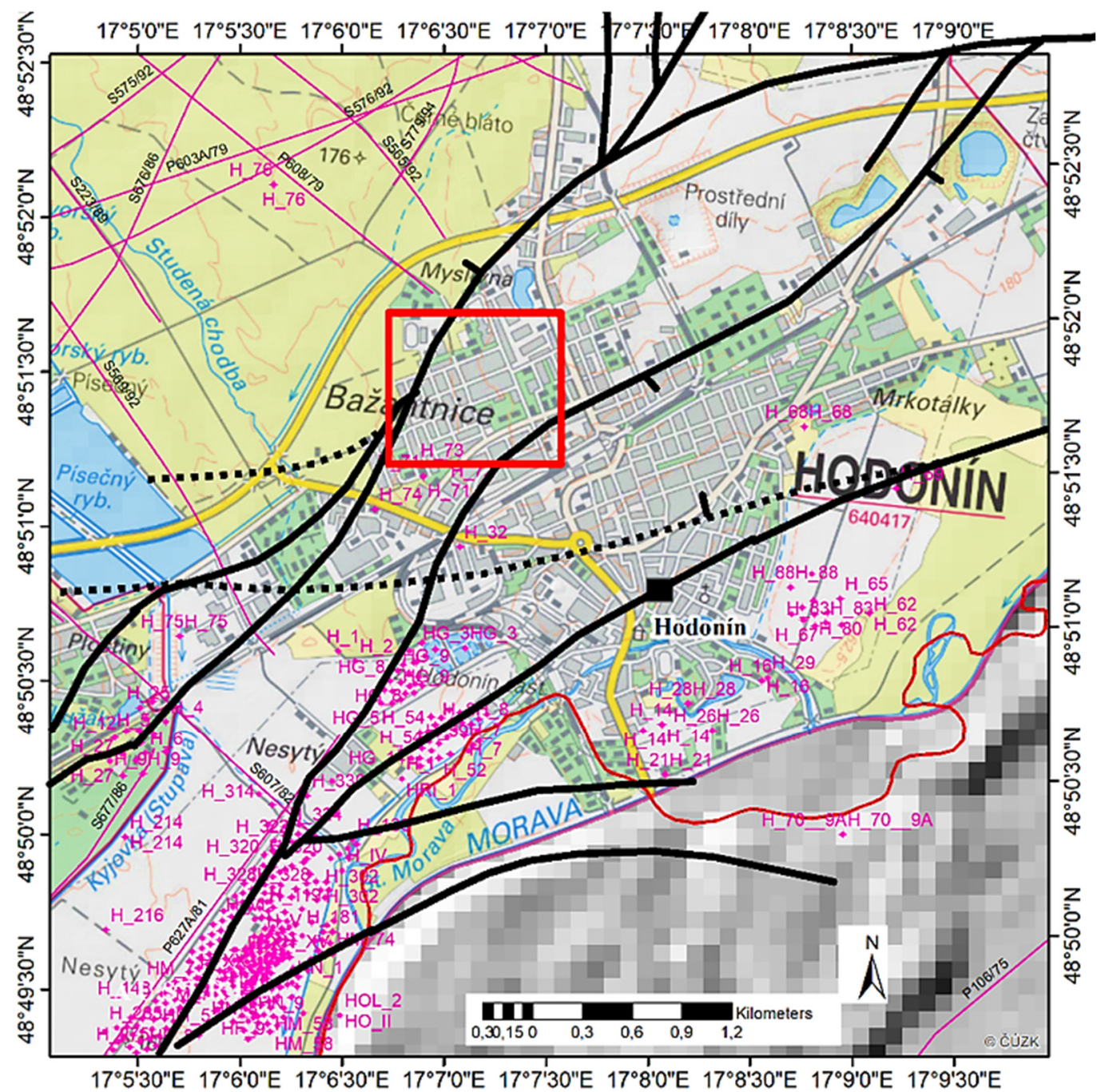

Fig. 3 Overview of tectonic condition in the area of interest supplied by hydrocarbon wells realized in the past. Black line - fault systems identified during intensive hydrocarbon exploration in area, violet lines reflection seismic sections, violet dotes with marks - wells. Red square - area of interest.

another 3-4 faults. According to reflective seismic measurements, their range is of the order of several $\mathrm{km}$, intersecting the entire Neogene power of the Vienna Basin. Their recent activity was recorded just near the UGS along to the Tvrdonice - Hodonín fault.

\section{GEOLOGICAL, GEOLOGICAL-ENGINEERING AND GEOPHYSICAL EXPLORATION}

Geological, geological-engineering and geophysical knowledge of the Bažantnice area is only partial. In the area of interest, there are several dozen older wells of various depths, irregularly distributed, which do not allow to determine the general causes of subsoil failures.

The first geophysical surveys were performed by Kolejconsult servis, Ltd. 2005 and 2007 at the most deirupted houses (Streets Křčckova 31, Krričkova 33-37 and Bř́ Čapků 15-17). In all three cases, large and deeply affected zones were found under the individual buildings. The main cause of the subsoil instability was seen in the existence of a depressive structure on the surface of the underlying blue-gray massive clays.

After about ten years, in 2016 and 2017, further surveys were carried out at next two localities (Streets I. Olbracht 10-12 and I. Olbracht 9-11). The same depressive structures of the strongly weakened subsoil were found under the objects of interest.

This fact led the city officials to commission a basic geophysical survey of the entire Bažantnice Housing Estate in order to determine the general causes of the gradual deterioration of the subsoil, which results in settling of soils and the occurrence of failures in residential buildings.

\section{METHODOLOGY OF RESEARCH}

The geophysical survey carried out in the entire area of the Bažantnice housing estate (BHE) was based on the Georadar method (GPR) with a frequency of $100 \mathrm{MHz}$. The measurements covered the entire area of interest so that at least one profile ran between individual houses (Fig. 2), which in the final allowed 


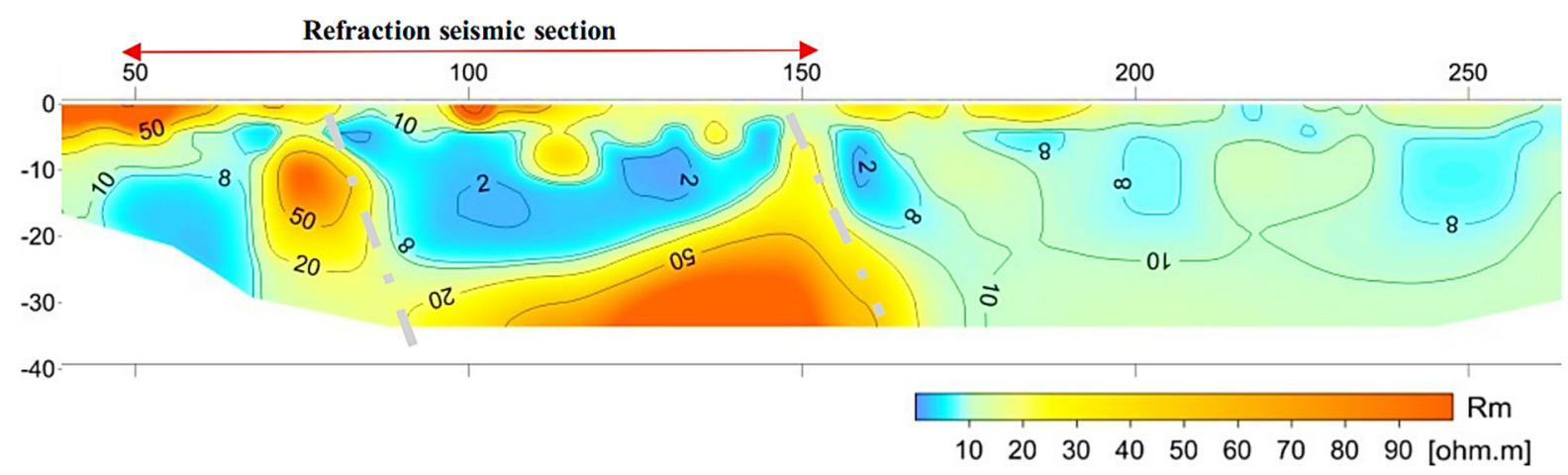

Fig. 4 Model resistivity obtained by ERT measurements.

S1-2.DAT $\quad x$-distance $[\mathrm{m}]$

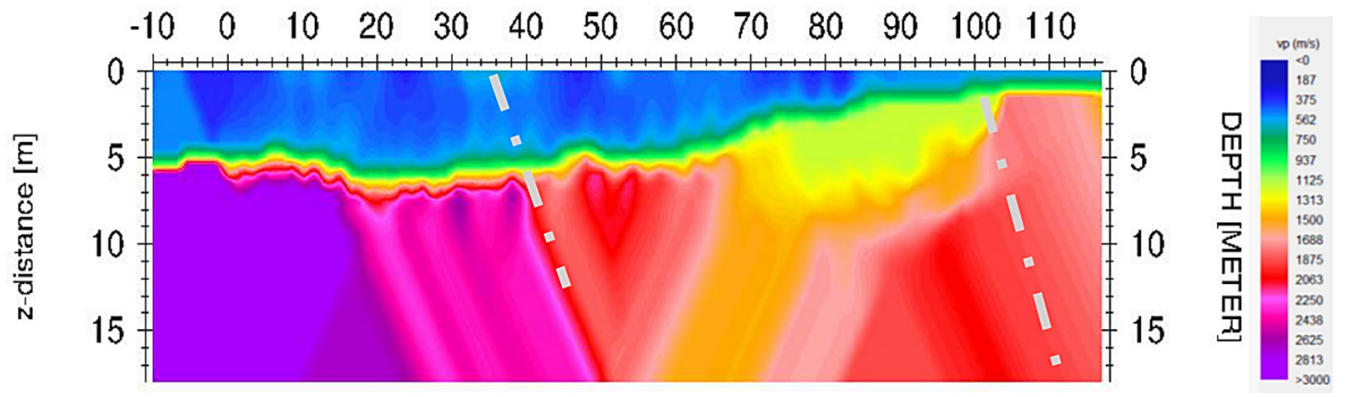

Fig. 5 Example of the seismic refraction section, which determines the position of low velocity layer assigned to cover formations created by Quaternary and weathered part of the Neogene subsoil.

the calculation of horizontal sections physical parameters. Another method, which covered the entire area of BHE, was the measurement of conductivity by the method of dipole electromagnetic profiling DEMP. Complementary methods that have been used to obtain the physical parameters of the rock environment are resistance (ERT) and seismic (MRS) tomography.

\section{GEOPHYSICAL AND ENGINEERIG GEOLOGICAL SURVEYS}

The position and character of the presumed fault lines were confirmed by ERT resistance tomography measurements, when on the profile situated on J. Suka Street, near the intersection with Křičková Street, two fractures of a declining character were recorded, which limit the northern edge of the partial Neogene basin (Fig. 4).

An important finding is the increase of seismic velocities at the fracture site, where it increases from an average of 400 to $500 \mathrm{~m} / \mathrm{s}$ to 1300 to $1400 \mathrm{~m} / \mathrm{s}$ (green-yellow area). This local increase in velocities at the fracture structure can be explained by the increase in humidity. This finding shows that groundwater also moves along the faults.

\section{RESISTIVITY TOMOGRAPHY}

Model resistivity (Fig. 4) obtained by ERT measurements range from units to the first hundred of ohmmeters. The lowest resistivities that occur in the geoelectrical resistivity models are only $2 \Omega \mathrm{m}$, the highest recorded resistivity is $200 \Omega \mathrm{m}$. The predominant value of the resistivity model is in the range of 10 to $20 \Omega \mathrm{m}$, which corresponds to a clayey, partly slightly sandy rock environment.

1. Layers of low resistivities of 2 to $8 \Omega \mathrm{m}$ are considered extremely low and we associate them with the occurrence of geologically unstable positions, either disturbed and slushed clays or strongly waterlogged and liquid sands.

2. Layers of high resistivities above $50 \Omega \mathrm{m}$ are associated with the occurrence of Neogene sands.

Velocity inversion - thinning of the low velocity layer. Occurrence of locally limited layers in overburden formations with velocities of 900 and $1300 \mathrm{~m} / \mathrm{s}$. It is a place where the soil is waterlogged or heavily humidified.

\section{GPR MEASUREMENTS}

Ground Penetreting Radar (GPR) measurements were performed on 132 profiles L0 to L131. Radar profiles were located on geophysical lines running through the center of individual streets or between individual apartment blocks. The aim of the measurement was to obtain sufficient coverage of the area of interest for the subsequent calculation of horizontal scans. The profiles were measured in continuous mode with the same parameters. A total of 19,692 m of georadar profiles were measured. 

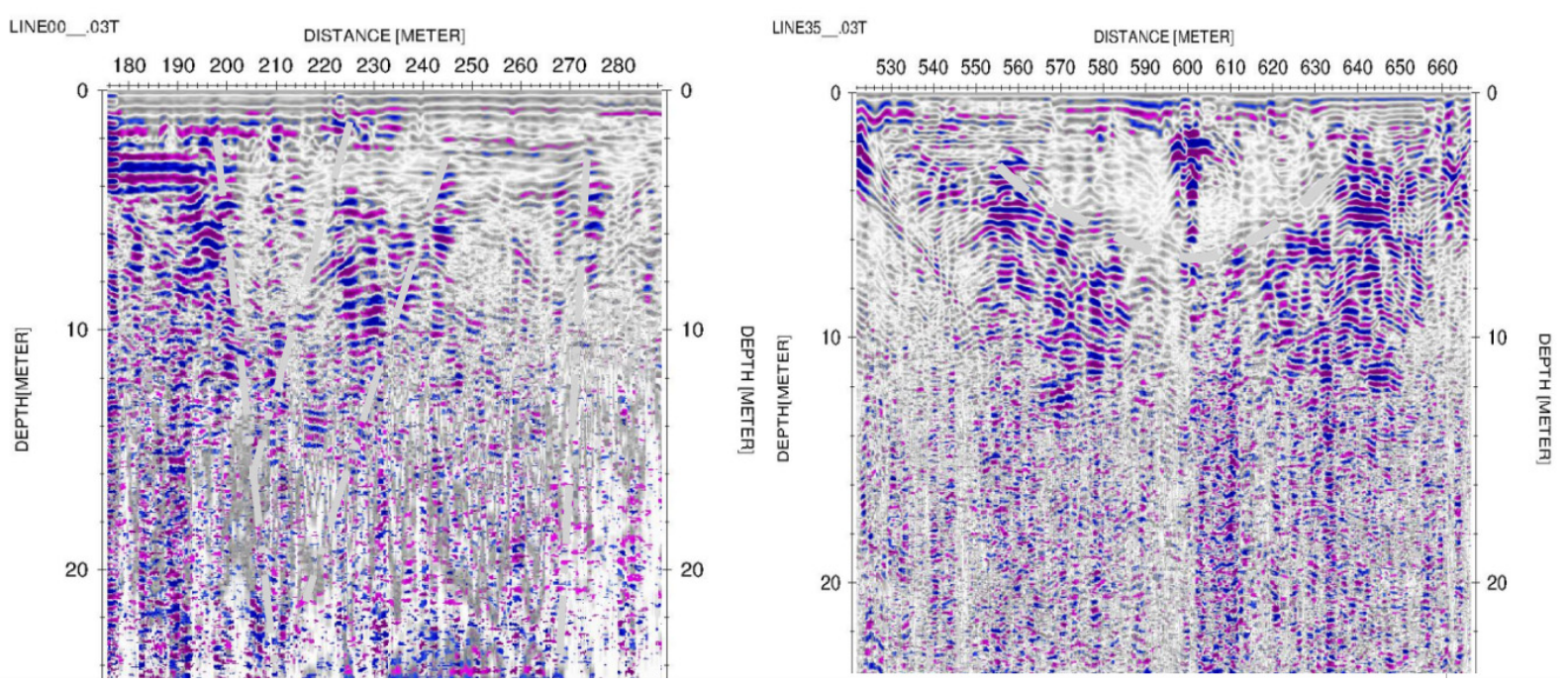

Fig. 6 Demonstration of georadar records on the condition of the subsoil to a depth of up to $20 \mathrm{~m}$ : left - course of main tectonic indications, right - display the condition of the subsoil at different depth levels.

Radar data processing in REFLEXW 8 included the following signal modification:

- Noise filtering (diffraction stack for speed $0.3 \mathrm{~m} / \mathrm{ns}$ and five consecutive velocity).

- Calculation and implementation of a 2D velocity model based on direct velocity measurement by the CMP method at the site and conversion of the time section to depth section.

- Calculation of autocorrelation function to increase wave field coherence.

The output of georadar records was performed in the mode of conservation of real amplitudes (Energy Decay) to highlight the structure of the wave field and local anomalies. The obtained georadar records are very high quality and show the condition of the subsoil to a depth of up to $20 \mathrm{~m}$ (Fig. 6A).

- The main output of georadar measurements are areal georadar scans, reflecting the physical state of the subsoil at different depth levels. Based on the scan at a depth of 3 to $4 \mathrm{~m}$ (cover base - Fig. 6B), it was possible to correlate the course of the main tectonic indications and other faults or lithological interfaces (Fig. 7).

\section{SATELLITE RADAR INTERFEROMETRY}

Satellite Synthetic Aperture Radar (SAR) interferometry (InSAR) is an effective method for monitoring mainly vertical displacements and deformations of terrain or objects of infrastructure. It relies on decades of research using repeat-pass satellite SAR imagery to extract information about physical displacements of observed scatterers from differences of the satellite SAR signal delay. A differential combination of SAR phase measurements (i.e. phase of the portion of retroreflected electromagnetic wave of the radar) between two images is called an interferogram. An interferogram contains information about displacements over observed area between times of acquisitions taken from the same orbital track of the satellite. Because the SAR wavelength is in the order of centimeters, the interferometric phase is sensitive to subtle displacements in the order of millimeters or centimeters in the satellite line of sight (LOS) within the SAR resolution cell. In this work, we have used data from Copernicus Sentinel-1 constellation, having characteristics as a 6 days revisit time within the same orbital track, approx. $5.5 \mathrm{~cm}$ radar wavelength, pixel spacing of around $2.5 \times 14 \mathrm{~m}$ and the LOS ranging between $\sim 30-45$ degrees from nadir.

\section{PROCESSING DATA}

Processing of standard Sentinel-1 data is complex due to usage of so-called TOPS mode that needs a specific Enhanced Spectral Diversity (ESD) correction (Yague-Martinez et al., 2016) for InSAR processing. ESD correction can be achieved only using large-scale portions of the Sentinel-1 images by combinations of overlapping sub-images taken from slightly varying observing angle called bursts. Data should be preprocessed by coregistration, ESD correction and other phase corrections (e.g. Elevation Antenna Patterns, EAP), prior to their utilization for interferometric techniques. A specific way of data preprocessing has been implemented in IT4S1 monitoring system (Lazecky, 2017; Lazecky et al., 2020) that uses ISCE (Zebker et al., 2010) as the core processor for Sentinel-1 data. Here the data were preprocessed to form an InSAR analysis ready dataset.

Because of various error sources to InSAR due to its high sensitivity to atmospheric vapour variations or physical changes of such scatterers as vegetation etc. (Hanssen, 2001), the interferograms may get generated in a way suitable for their multitemporal combination. We have applied a typical multitemporal InSAR (MT-InSAR) technique - a Permanent/Persistent Scatterers (PS) 


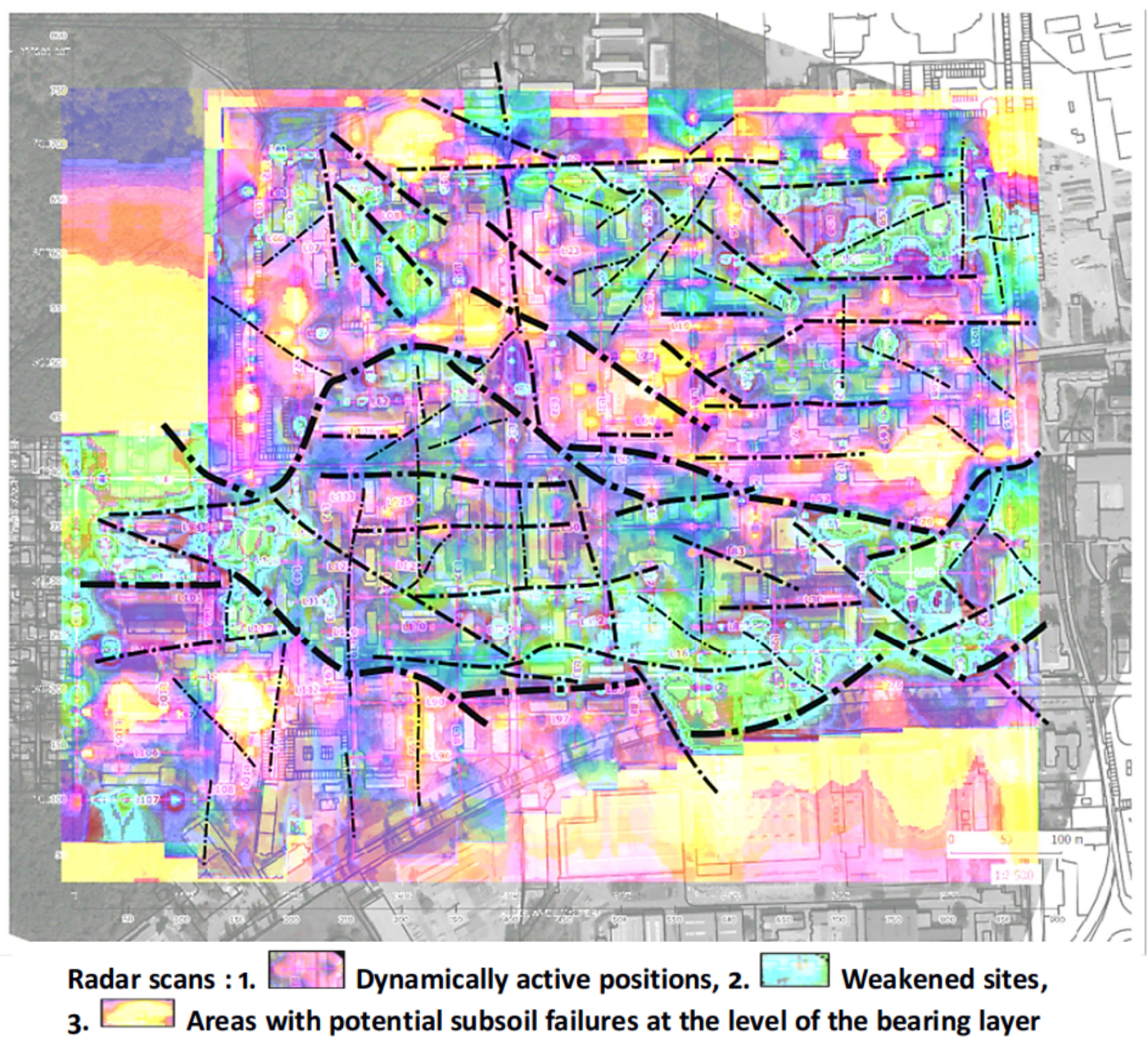

Fig. 7 The georadar scans, reflecting the physical state of the subsoil at depth of 3 to $4 \mathrm{~m}$, enable to correlate the course of the main tectonic indications and other faults or lithological interfaces.

technique (Ferretti et al., 2000) that generates interferograms in combination with one common reference image is applicable to objects with high temporal stability - typical objects serving as PS points (i.e. objects which signal is dominating over their decorrelating surroundings) are buildings and other structures or strong natural scatterers as e.g. bare nonvegetated rocks. This technique is valuable for its high reliability and precision reaching a millimeter per year (Ferretti et al., 2007).

After the preprocessing of Sentinel-1 data covering the area of interest (AOI) by IT4S1 approach, a PS algorithm implemented in a open-source STAMPS MT-InSAR package (Hooper, 2008) has been used to perform an MT-InSAR analysis, using burst-wise optimised parameters (Lazecky et al., 2020). Finally, estimated displacement time series within pixels and final maps of an average velocity were generated.

For a better estimation of satellite position and more accurate geocoding.

It should be noted that we have used precise orbital ephemerides by Sentinel-1 Quality Control Subsystem in this work, and a global SRTM DEM model (Farr et al., 2007) in its resolution of 1 arcsec (approx. $30 \mathrm{~m}$ ) for the elimination of the topographic signal.

We have performed a PS processing over two tracks, as described in Table 1, using the IT4S1 system (Lazecky et al., 2020). The average vertical look angle of both datasets is $39^{\circ}$ from $\sim \mathrm{W}$ (track 73) and $\sim \mathrm{E}$ (track 124) directions. As both tracks were showing similar results, we have assumed that the measured LOS values represent vertical displacements and neglected a possibility of horizontal $\sim \mathrm{W}$ - E deformation in InSAR outputs. Therefore we have merged PS outputs from both tracks into one layer and projected their values into the vertical direction using cosine of the incidence angle. The merged output is plotted in Figure 8, together with two example time series plots of points in the AOI. Afterwards, we have interpolated the merged output, as will be shown in Results section.

\section{RESULTS}

Basic geophysical research showed a relatively intensely tectonic disturbed rock environment (Fig. 9). The main fault line, passing through the western part of Bažantnice between J. Suka and Křičkova Streets in the direction W-E, splits. Its southern branch passes 
Table 1 Sentinel-1 dataset used for PS InSAR processing.

\begin{tabular}{lcccc}
\hline orbital track & Burst ID & Dates & Number of samples & Incidence angle \\
\hline Ascending & 73_2_7943 & $02 / 2015-10 / 2019$ & 209 & $\sim 39^{\circ}$ \\
Descending & 124_2_21587 & $03 / 2015-10 / 2019$ & 219 & $\sim 39^{\circ}$ \\
\hline
\end{tabular}
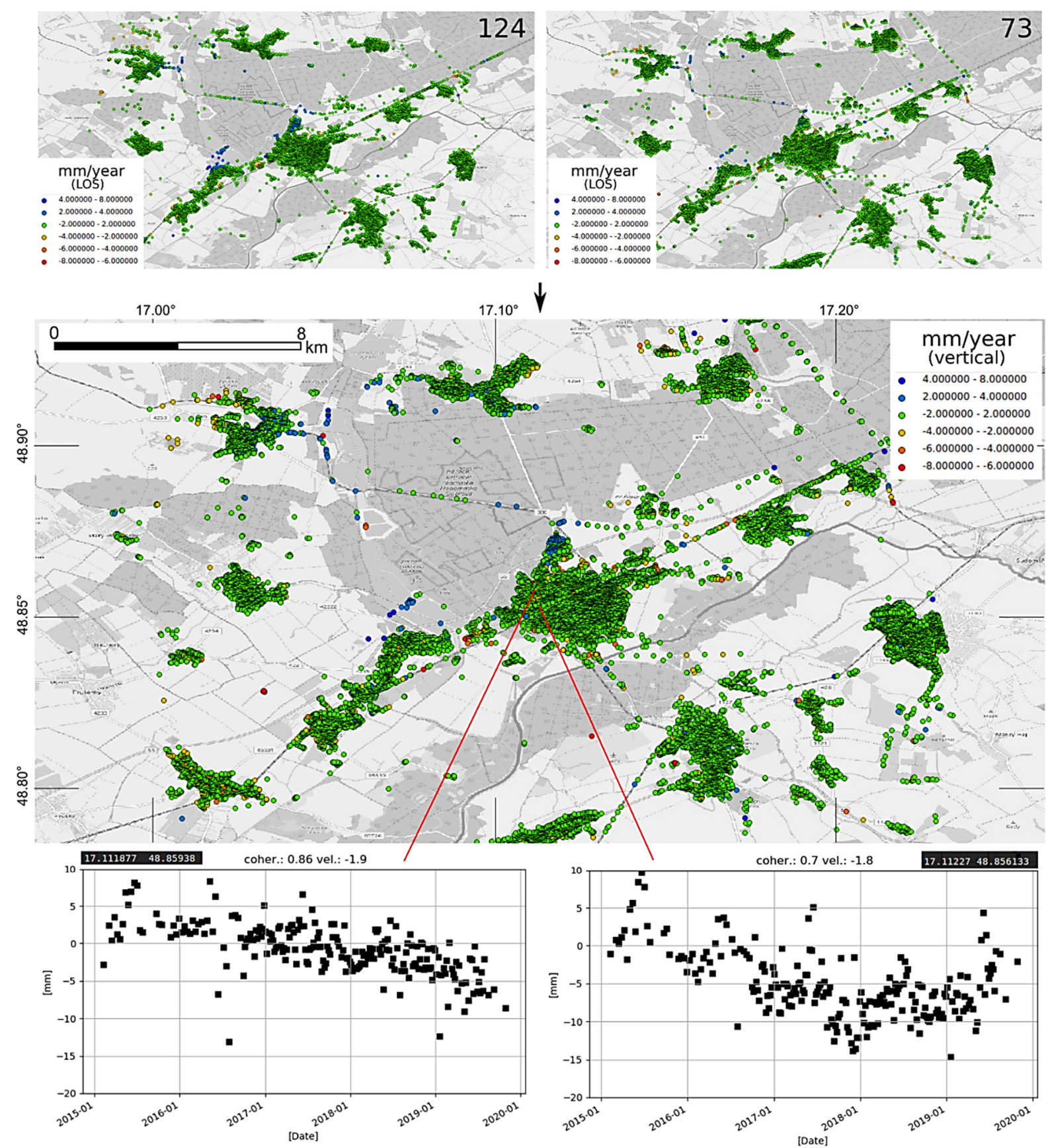

Fig. 8 Outputs of PS processing of Sentinel-1 data from tracks 73 and 124 (upper), their merged output projected to vertical displacements (middle) and two examples of time series plots in the AOI (bottom).

between Bří Čapků and Skácelova Streets. In addition to the main fault, we also locate a number of shear faults that have a tree structure. The existence of shear fractures is documented in the drilling cores, where we monitor the kneading of clays.

Along the main fault lines we define strips of weakened rocks. The worst situation is between J. Suka and Křičkova Streets. Here is also the largest number of severely damaged residential houses. At the same time, we are observing an increased incidence of waterlogged positions. The water enters the Bažantnice area from the north through the middle part of U Červených domků Street, and then rises along the main fault line.

The subsoil is destroyed by the degradation of a relatively load-bearing layer at a depth of 3 to $4 \mathrm{~m}$. 


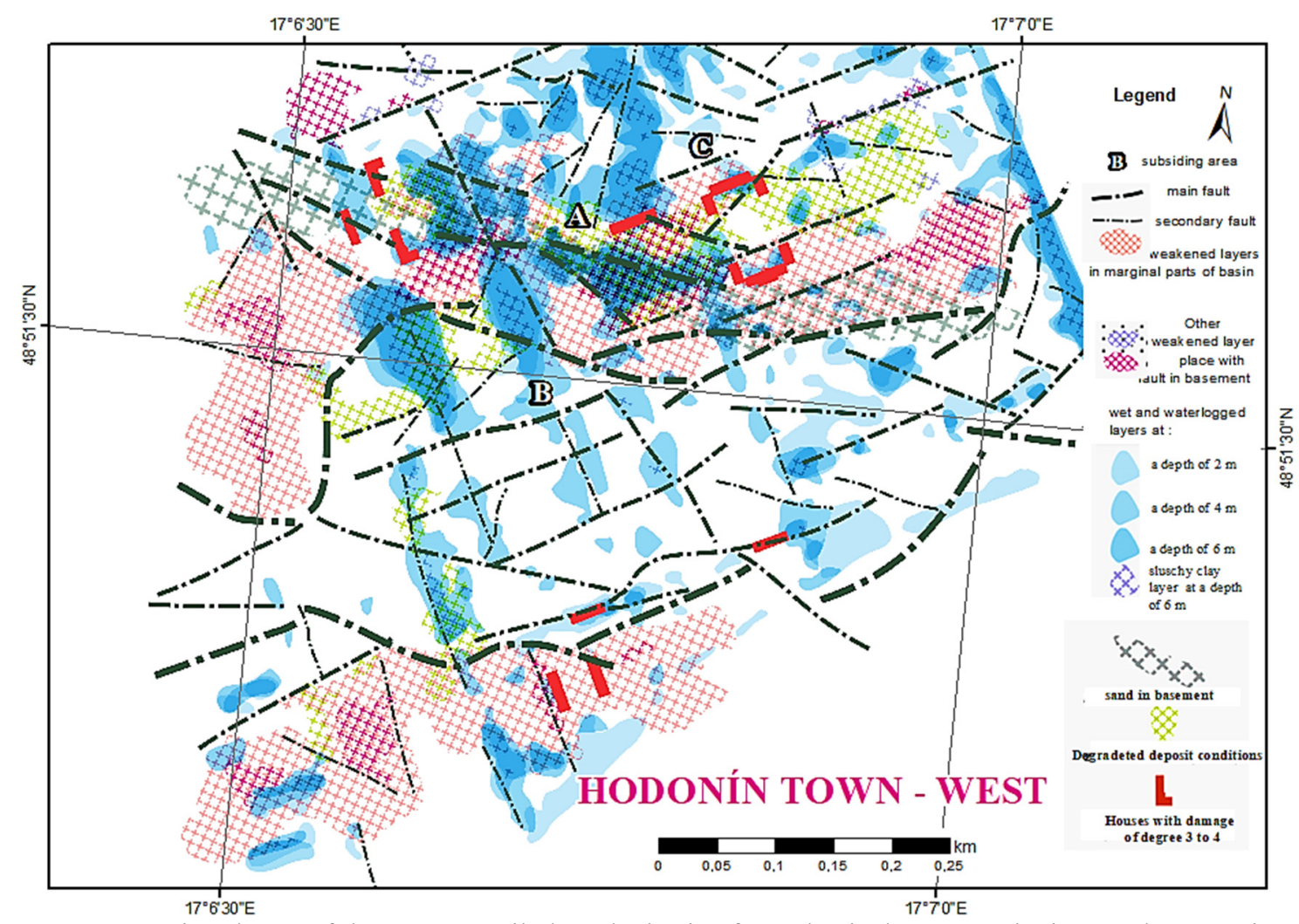

Fig. 9 Tectonic scheme of the area compiled on the basis of geophysical survey. The image shows an intensive tectonicaly disturbed rock environment. The main fault line, passes through the housing estate in the direction W-E. In addition to the main fault, a number of other shear faults of a typical flower structure were located. Most of the faults were confirmed by drilling cores.

It was found in the laboratory that clays taken from a depth of $2.0 \mathrm{~m}$ have higher bulk densities than clays taken deeper from $4.0 \mathrm{~m}$. This means that the same soils lying deeper have a higher porosity. The ongoing suffocation process remains an issue. Of the total number of 112 residential buildings, $6 \%$ are severely demolished and $9 \%$ of houses have moderately demolished masonry. In total, there are 16 to 17 residential houses, which are located along the main fault lines.

Following Figures 10-12 represent the interpolated output of the merged PS InSAR results, projected to the vertical direction. It should be noted that some less coherent points were used as input to the interpolation. However the outcomes show realistic features - e.g. relation to the Hrušky-Lužice fault system (Fig. 10). The InSAR-based vertical deformation velocity map of the Hodonín housing estate and its surroundings is shown in Figure 11, together with the main tectonic boundaries. Finally, Figure 12 shows the main deformation zone in the $\mathrm{W}-\mathrm{E}$ direction running across the housing estate, representing the main risk zone for this part of the town.

\section{CONCLUSIONS}

Extensive geophysical research of the site provided essential information about active faults in the long-term disturbed area of Hodonín town. Processed interferometric data from the Sentinel-1 SAR satellite were used to prove and define the most active deformation zones (blocks) in the area of the housing estate where a large part of the city's population lives. The current methodology of engineering-geological and geophysical survey was supplemented by the study of displacement tendencies using Sentinel-1 satellite technology. Results from the joint evaluation of geophysical data and InSAR not only confirmed the identified deformations but also notified on the extent and intensity of displacements and other possible problematic areas with tendencies to subsidence near to main faults (locations B, C, D and E) - faults D and E were already at the edges of the area. The results of interferometry provided suitable, additional information about areas with higher degree of subsidence and uplifting directly in the entire built-up area. The obtained results make it possible to take appropriate measures for the remediation of damaged blocks and thus contribute to the stabilization of individual buildings.

The combination of the presented methods for detection of tendencies to deformation in urbanized areas is very effective and can be successful in future for selection of construction locations or preparation of municipal zoning plans. Such analysis would help preventing possible future problems. 

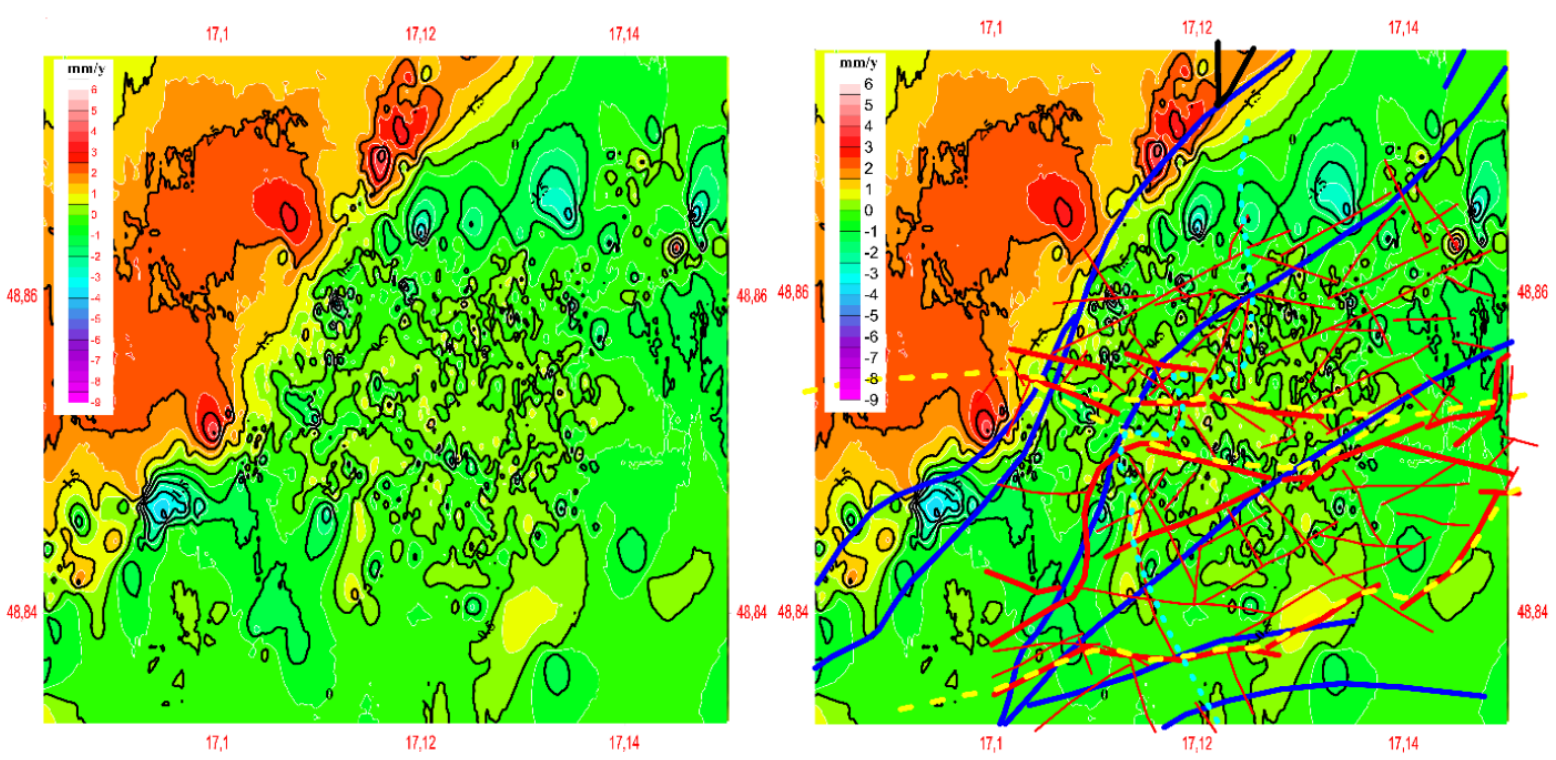

Fig. 10 Map of annual velocities in the wider region of the BHE in the Hodonín town. The uplifting tendencies along the Hrušky - Lužice fault system were very well detected. These may be related to the the hydrocarbon reservoirs structures and the nearby gas reservoir Dolní Bojanovice. The large number of faults in the BHE correlates well with the identified vertical movement tendencies. The influence of the central fault zone of the $\mathrm{W}$-E direction is clearly visible, too.

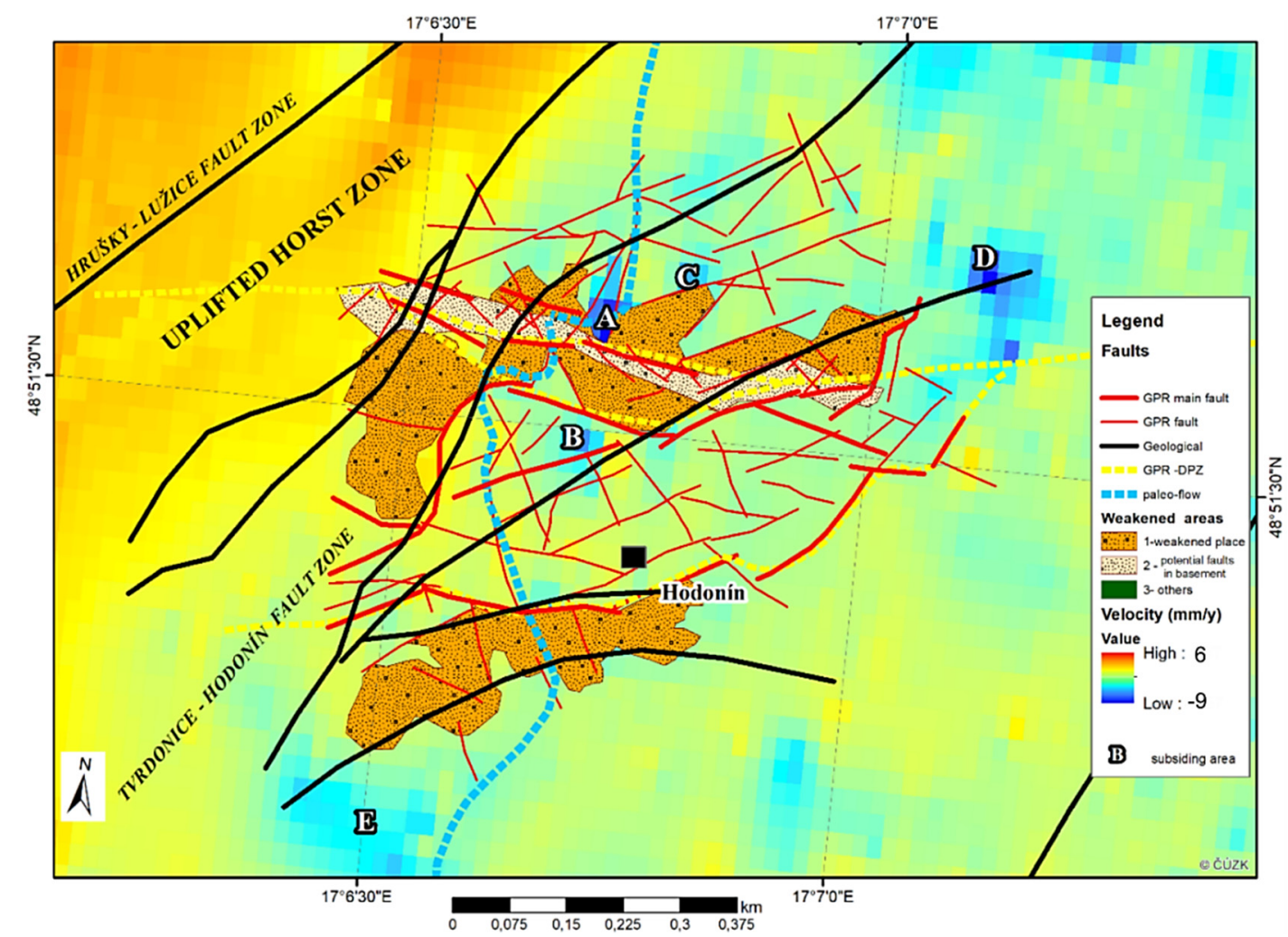

Fig. 11 The InSAR-based vertical deformation velocity map of the Hodonín housing estate and its surroundings supplemented by the main tectonic boundaries. Brown dotted areas delimit the most disturbed places. The red areas, behind the Hrušky - Lužice fault, reflect the block connected to the area where UGS Dolní Bojanovice is located. Letters A-E indicate places with maximum of subsidence.

\section{FUNDING}

This work partially supported by Grant of SGS No. SP2019/64, Faculty of Mining and Geology, VSB - Technical University of Ostrava. This work was partially supported by Municipality of Hodonín, Kolej Service and by The Ministry of Education, Youth and Sports. 


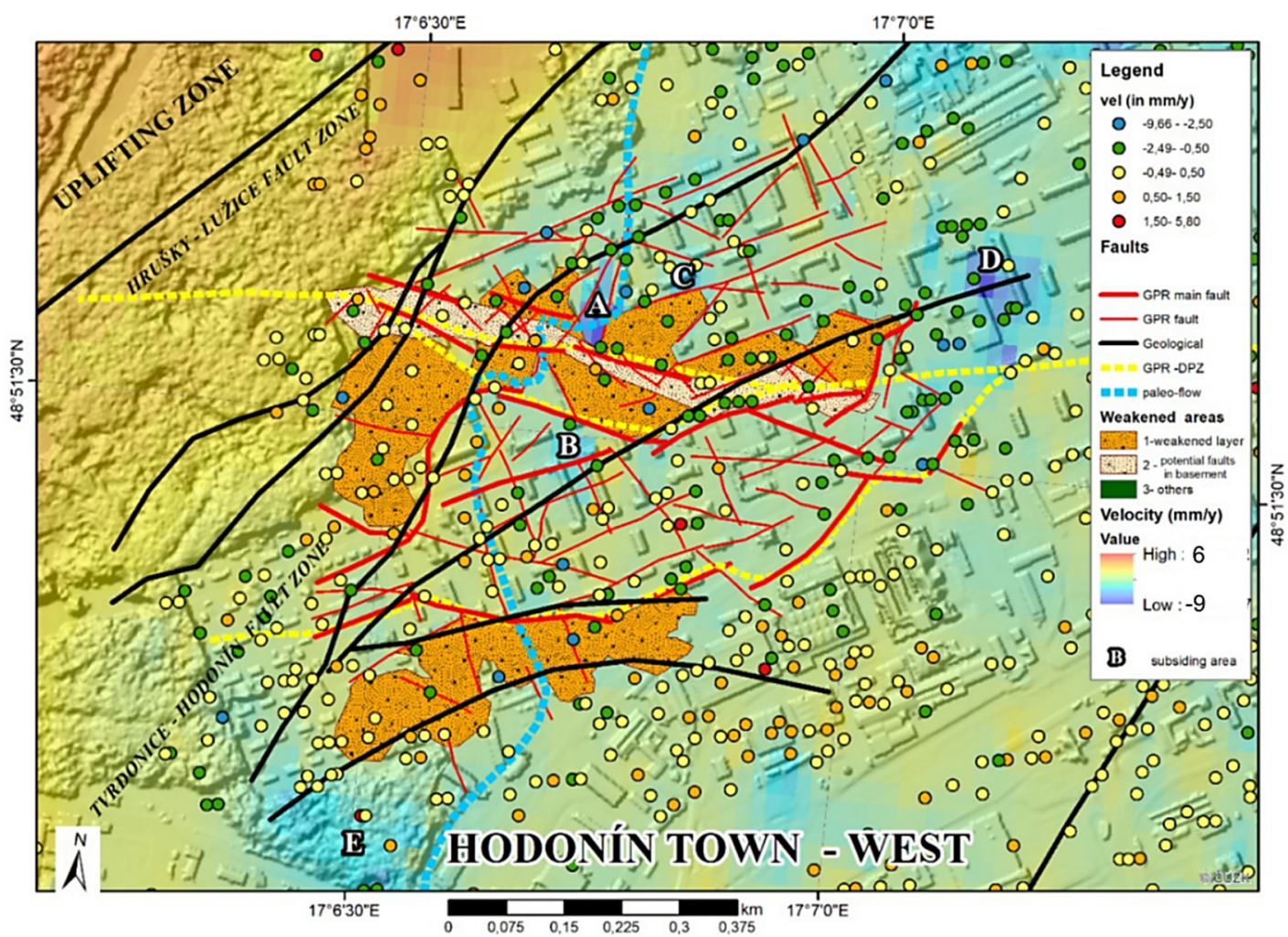

Fig. 12 The same results are presented over the zoning plan of the city of Hodonín. The main deformation zone in the W-E direction runs across the housing estate and represents the main risk zone for this part of the town.

\section{ACKNOWLEDGMENTS}

This work was supported by The Ministry of Education, Youth and Sports from the National Programme of Sustainability (NPU II) project "IT4Innovations excellence in science - LQ1602". This paper contains modified Copernicus Sentinel-1 data 2015-2019, processed by ESA, retrieved from Czech Copernicus Collaborative Ground Segment (operated by CESNET).

\section{REFERENCES}

Farr, T.G., Rosen, P.A., Caro, E., Crippen, R., Duren, R., Hensley, S., Kobrick, M., Paller, M., Rodriguez, E., Roth, L. et al.: 2007, The shuttle radar topography mission. Rev. Geophys., 45, 2. DOI: $10.1029 / 2005 R G 000183$

Ferretti, A., Prati, C. and Rocca, F.: 2000, Nonlinear subsidence rate estimation using permanent scatterers in differential SAR interferometry. IEEE Trans. Geosci. Remote Sens., 38, 5, 2202-2212. DOI: $10.1109 / 36.868878$

Ferretti, A., Savio, G., Barzaghi, R., Borghi, A., Musazzi, S., Novali, F., Prati, C. and Rocca, F.: 2007, Submillimeter accuracy of InSAR time series: Experimental validation. IEEE Trans. Geosci. Remote Sens., 45, 5, 1142-53. DOI: $10.1109 /$ TGRS.2007.894440

Hanssen, R.F.: 2001, Radar interferometry: data interpretation and error analysis. Dordrecht, Kluwer Academic Publishers, 308 pp.
Hooper, A.: 2008, A multi-temporal InSAR method incorporating both persistent scatterer and small baseline approaches. Geophys. Res. Lett., 35, 16. DOI: 10.1029/2008GL034654

Lazecky, M.: 2017, System for automatized Sentinel-1 interferometric monitoring. Proc. Conference on Big Data from Space, Toulouse, France, 28-30 November 2017, 161-165.

Lazecký, M., Hatton, E., González, P.J., Hlaváčová, I., Jiránková, E., Dvořák, F., Šustr, Z. and Martinovič, J.: 2020, Displacements monitoring over Czechia by IT4S1 system for automatized interferometric measurements using Sentinel-1 data. Remote Sens. 12, 18, 2960. DOI: 10.3390/rs 12182960

Rapant, P., Struhár, J. and Lazecký, M: 2020, Radar interferometry as a comprehensive tool for monitoring the fault activity in the vicinity of underground gas storage facilities. Remote Sens., 2, 271-289. DOI: $10.3390 /$ rs 12020271

Yague-Martinez, N., Prats-Iraola, P., Gonzalez, F.R., Brcic, R., Shau, R., Geudtner, D., Eineder, M. and R. Bamler, R.: 2016, Interferometric processing of Sentinel-1 TOPS data. IEEE Trans. Geosi. Remote Sens., 54, 115. DOI: $10.1109 /$ TGRS.2015.2497902

Zebker, H.A., Hensley, S., Shanker, P. and Wortham, C.: 2010, Geodetically accurate InSAR data processor. IEEE Trans. Geosci. Remote Sens., 48, 12, 43094321. DOI: 10.1109/TGRS.2010.2051333 